DOI https://doi.org/10.30525/978-9934-26-073-5-2-10

\title{
ТРАНСФОРМАЦІЇ НАЙМЕНУВАНЬ АРТЕФАКТІВ ЗА МЕТАФОРИЧНОЮ МОДЕЛЛЮ «АРТЕФАКТ - АРТЕФАКТ»
}

\author{
Буранова А. В. \\ кандидат філологічних наук, \\ старший викладач кафедри методики викладання іноземних мов \\ Національного педагогічного університету імені М. П. Драгоманова \\ м. Київ, Украӥна
}

У сучасній лінгвістиці широко використовується методика метафоричного моделювання (А.Н. Баранов, Ю.М. Караулов, О.Н. Кондратьєва, Ю.В. Кравцова, Н.О. Мішанкіна, Г.М. Скляревська, В.М. Телія, А.П. Чудінов та ін.), яка дає можливість аналізувати транспозиції найменувань, в тому числі назв артефактів. Під артефактом розуміємо будь-які штучно створені предмети.

У попередніх дослідженнях було виявлено, що трансформації найменувань артефактів відбуваються за метафоричними моделями «артефакт - артефакт», «артефакт - людина» «артефакт - абстракція» та «артефакт - геометричні фігури». Встановлено, що у всіх досліджуваних мовах регулярні метафоричні перенесення найчастіше відбуваються за моделлю «артефакт - абстракція» (укр. 84,7\%, нім. 85,6\%, англ. 86,3\%), що пов'язано 3 прагненням людини закріпити абстрактне поняття в образі матеріального предмета для більш доступного сприйняття його розумом та збереження в пам'яті [1, с. 279].

Г.М. Скляревська розміщує лексику семантичної сфери «Предмет» у трьох розділах: 1) природні об'єкти; 2) предмети, створені людиною; 3) предмети, які є логічно виділеними людиною [3, с. 68]. На основі цієї класифікації у структурі метафоричної моделі «артефакт - артефакт» виділяємо дві субмоделі: «артефакт - артефакт» та «артефакт натурфакт», де семантичний розвиток здійснюється за вектором «конкретне - конкретне».

Метою даного дослідження $\epsilon$ аналіз назв артефактів, переносне значення яких утворилось за метафоричною моделлю «артефакт артефакт» в українській, німецькій та англійській мовах.

1. Субмодель «артефакт-артефакт»

За цією субмоделлю метафоричне переосмислення відбувається на основі подібності за формою, за функцією та за ознакою. 
Наведемо приклади метафоричного перенесення на основі подібності за формою. До цієї метафоричної субмоделі можна віднести безаналогове переносне значення німецького найменування der Kranz «вінок» - «пиріг». Передумовою виникнення цієї транспозиції є подібність за формою пирога, який нагадує вінок: kranzförmiger Kuchen, Kranzkuchen «пиріг у формі вінка»; einen Kranz backen «пекти пиріг»; ein Stück Kranz «шматок пирога» [5]. Крім цього, українське найменування простирадло використовується на позначення «великого листа паперу» [4, Т. 8, с. 297], а англійська назва peg «кіл» набула переносного значення «підніжка на мотоциклі» [6].

У ході дослідження було зафіксовано також метафоричне перенесення на основі подібності за функцією. Так, англійська номінація coffin «труна» характеризується нерівнозначністю переносного значення по відношенню до української та німецької мов. Найменування позначає «засіб пересування», причому з негативним відтінком: 1.1 informal An old and unsafe aircraft or ship «неформально Старий та ненадійний літак чи корабель»; Protestors call the country's airplanes flying coffins «протестуючі називають літаки країни летючими трунами»; The increased use of aeroplanes in warfare led to such terms as Beauey, biscuit bomber, and flying coffin «більш широке використання літаків у бойових діях призвело до таких термінів як Биайе, бомбардувальник печер та летюча труна» [6]. Ймовірно, труна виступає як засіб переміщення покійника на той світ, що порівнюється з засобом пересування. Отже, це метафора за функційною подібністю. Також за функційним призначенням українське найменування замок набуло переносного значення «будинок» [4, T. 3, с. 218], німецька назва der Putz «штукатурка» позначає «одяг» [5], а англійське найменування соор «клітка» - «в'язницю»[6].

Під час дослідження було встановлено, що метафоричне перенесення здійснюється також на основі подібності за ознакою. Так, англійська назва jug «Глек» має безаналогове переносне значення «в'язниця» [6]. У цьому випадку артефакт jug, очевидно, порівнюється 3 prison «в'язниця» на основі своєї циліндричної форми, через яку важко щось дістати 3 дна предмета, так само, як важко вибратися з в'язниці: A cylindrical container with a handle and a lip, used for holding and pouring liquids «циліндричний контейнер з ручкою та краєм, що використовується для утримання та розливання рідин» [6]; Crenshaw has spent long enough in the jug...»Кренша провів дуже довго у в'язниці» [6].

У всіх досліджуваних мовах зафіксоване переносне значення «брудне приміщення» для найменування укр. хлів / нім. der Stall / англ. barn. Мотиваційною ознакою перенесення $є$ «брудний», оскільки артефакт 
використовується для утримання свійської худоби чи тварин [4, Т. 11, с. 83]. Пор. укр. // перен., розм. Брудне, неприбране, занедбане приміщення. [Степан:] Свахо, не комизься, іди в хату! [Настя:] Яка я тобі сваха? Щоб ти й доки світ сония не діждав бачити мене у своїм хліві!.. [4, там само]; нім. salopp Raum, Wohnraum, Gebäude «фамільярно кімната, житло, будівля»; wir müssen den Stall mal gründlich ausmisten «ми повинні ретельно прибрати приміщення» [5]; англ. $1.2 \mathrm{~A}$ large and uninviting building «велика та неприваблива будівля»; He had a whole room of metal-working equipment, a room full of wood-working equipment, and this huge barn of a room for electronics « У нього була ціла кімната металообробного обладнання, кімната, повна деревообробного обладнання, і цей величезний сарай з приміщення для електроніки» [6]. Треба відзначити, що аналогічне переносне значення має у досліджуваних мовах найменування укр. свинарник / нім. der Schweinestall / англ. pigsty. В основу цієї метафори лягла та ж сама мотиваційна ознака. Пор. укр. переможно говорить тато, так-так, друзі, баба, ну ви мене знаєте, я таких не пропускаю, щчо, кицю, говорю, щчо ти робиш у цььому свинарнику? [2]; нім. salopp, übertragen unordentlicher, schmutziger Raum «фамільярно, переносно недбале, брудне приміщення»; in diesem Schweinestall kann man doch nicht arbeiten! «у цьому свинарнику не можна працювати» [5]; англ. 1.1 A very dirty or untidy house or room «дуже брудна чи занедбана кімната»; Maybe she could move in with her brother, but remembering what a pigsty her brother's house is, she knew she'd be left to pick up after his mess " Можливо, вона могла б переїхати разом 3 братом, але, пам'ятаючи, який свинарник у її брата, вона знала, що їй доведеться забратися після невдач» [6]. Транспозиції отримають негативне забарвлення в усіх мовах, оскільки на їх основі позначаються брудні та неохайні приміщення.

Аналогові переносні значення отримали також українська назва ганчірка та німецьке найменування der Luтреn «жмутик», що застосовуються на позначення «одягу» [4, Т. 2, с. 27; 5]. В основу перенесення покладена подібність за ознакою «зношеність», оскільки ці артефакти, як правило, позначають стару тканину, переважно у зім'ятому вигляді, чим i характерний одяг, який довго носять.

2. Субмодель «артефакт-натурфакт»

Як відомо, прадавня людина велике значення надавала небесним світилам. На нашу думку, на основі давніх вірувань людей утворилися метафоричні перенесення за субмоделлю «артефакт - натурфакт». Однак ця субмодель $\epsilon$ малопоширеною. У ході дослідження зафіксоване переносне значення «місяць» для української назви серп. Мотиваційною 
ознакою транспозиції $є$ подібність за дугоподібною формою небесного тіла. У тлумачному словнику вказується, що артефакт позначає: // Місяць у початковій або кінцевій фазі, коли із Землі видно лише частину його освітленого Сонцем диска; $B$ густій блакиті мліють вишняки, Сріблястий серп спустивсь На обрис хати; Блиснув на небі серп; В иентрі глибокого темно-синього неба плив тонкий сріблястий серп місяия [4, Т.9, с. 139]. Таке ж переносне значення має аналогічне німецьке найменування die Sichel: die schmale, scharfe, klare, weiße, Sichel am nächtlichen Himmel «вузький, чіткий, ясний, білий місяць на нічному небі»; die silberne Sichel am nächtlichen Himmel »сріблий місяць на нічному небі» [5]. Треба зазначити, що це значення використовується у німецькій мові переважно у високому стилі. В англійській мові не було зафіксовано рівнозначного метафоричного перенесення, однак назва sickle застосовується на позначення небесного тіла у складі словосполучення a sickle тооп «серп місяця».

Таким чином, метафорична модель «артефакт - артефакт» (укр. 6,1\% / нім. 20,4\% / англ. 6,8\%) є менш поширенішою, ніж інші. Зафіксовано, що у досліджуваних мовах спостерігаються як подібності між переносними значеннями, так і відмінності, що виявляються у безаналоговості метафор. Схожості можна пояснити властивістю однакового психічного сприйняття світу, в той час як відмінності говорять про унікальність асоціативного мислення різних народів.

\section{Лiтература:}

1. Буранова А.В. Метафоричне переосмислення назв артефактів за вектором «конкретне - абстрактне» // Актуальні питання гуманітарних наук: міжвузівський збірник наукових праць молодих вчених Дрогобицького державного педагогічного університету імені Івана Франка / [редактори-упорядники М. Пантюк, А. Душний, І. Зимомря]. Дрогобич: Видавничий дім «Гельветика», 2020. Вип. 31. Том 1. С. 278-284. http://www.aphn-journal.in.ua/archive/31_2020/part_1/43.pdf2

2. Загребельний П. День шостий [Електронне видання]. URL: http://www.ukrlib.com.ua/books/printit.php?tid=4337\&page=18 (дата звернення: 19.03.2021).

3. Скляревская Г.Н. Метафора в системе язика. Спб: Наука, 1993. $152 \mathrm{c}$.

4. СУМ : словник української мови : в 11 т. К. : Наукова думка, 1979-1980. T. 1-11. [Електронне видання]. URL: http://sum.in.ua/ (дата звернення: 22.12.2020). 
5. Digitales Wörterbuch der deutschen Sprache [Електронне видання]. URL: https://www.dwds.de/ (дата звернення: 02.02.2021).

6. English Oxford Living Dictionaries [Електронне видання]. URL: https://en.oxforddictionaries.com/ (дата звернення: 24.01.2021).

DOI https://doi.org/10.30525/978-9934-26-073-5-2-11

\title{
ОСОБЛИВОСТІ ЗАСТОСУВАННЯ СТРУКТУРНОГО МЕТОДУ В МОВОЗНАВЧИХ ДОСЛІДЖЕННЯХ
}

\author{
Волянюк I. О. \\ кандидат філологічних наук, \\ доиент кафедри української мови і літератури та методик їх навчання \\ Кременечької обласної гуманітарно-педагогічної академії \\ імені Тараса Шевченка \\ м. Кременещь, Тернопільська область, Україна
}

Загальновідомо, що мова $є$ системою. Вона складається з ієрархічно вибудуваних мовних рівнів, які поділяють на дві групи: основні та проміжні. Під рівнями розуміємо «деякі „ділянки» мови, підсистеми мовної системи, кожну 3 яких характеризують сукупність відносно однорідних одиниць і набір правил, які регулюють їх використання i групування в різні класи і підкласи» [2, с. 214]. До основних рівнів належать ті, що мають основну одиницю. 3-поміж них: фонологічний, морфологічний, лексичний і синтаксичний. У мові, як і в будь-якій системі, одиниці одного рівня взаємодіють із одиницями інших рівнів. Саме завдяки такій взаємодії функціонують проміжні рівні. До них відносять морфонологічний, словотвірний і фразеологічний.

У сучасних методологічних працях науково описано низку методів, за допомогою яких здійснюються мовознавчі дослідження різного характеру. Проте лінгвістичних розвідок, присвячених вивченню застосування структурного методу для дослідження мовних одиниць різних рівнів обмаль. 3 огляду на це тему нашої роботи вважаємо актуальною.

Тож метою публікації є обгрунтування важливості структурного методу в лінгвістичних дослідженнях, а також аналіз його прийомів під час вивчення одиниць мови.

Що ж називається структурним методом у лінгвістиці? За визначенням М. Кочергана, - це «метод синхронного аналізу мовних явищ лише на основі зв'язків і відношень між мовними елементами» 46 